\title{
EFFECT OF INTERVAL RUNNING AND SWIMMING ACTIVITIES ON SELECTED BIOCHEMICAL VARIABLES
}

\author{
MR. M. SENTHILKUMAR ${ }^{1}$ AND DR. A.G. VENKATESAN ${ }^{2, *}$ \\ ${ }^{1}$ Ph.D., Scholar and ${ }^{2}$ Assistant Professor, Department of Physical Education and Sports Sciences, Annamalai University. \\ *Corresponding Author Ph: +91 4565 224400; Email: yogakalyanam76@yahoo.co.in
}

\section{DOI: $10.26524 / 1237$}

\begin{abstract}
$\underline{\text { Abstract: }}$
The purpose of the study was to find out the effect of interval running and swimming activities on selected biochemical variables. Thirty male teachers aged between 35 and 40 years who knows swimming were selected for the study. They were divided into three equal groups, each group consisted of ten subjects in which Group I underwent interval running activity and group II underwent interval swimming activity, three days per week for twelve weeks and group III acted as control, who did not participate in any training. The subjects were tested on selected criterion variables such as total cholesterol, triglycerides and high -density lipoprotein, at prior to and immediately after the training period. The selected criterion variables, such as, total cholesterol, triglycerides and high density lipoproteins were assessed by using Boehringer Mannheim kit method. The analysis of covariance (ANCOVA) was used to find out the significant differences if any, between the experimental groups and control group on selected criterion variables separately. Since, three groups were involved in the present study, the Scheffé $S$ was used as post-hoc test. The results of the study showed that the selected criterion variables such as total cholesterol and triglycerides were decreased significantly and high-density lipoprotein was increased significantly for both the training groups when compared with the control group. Moreover, the result of the study also shown that there was no significant difference was occurred between the training groups on selected criterion variables such as, total cholesterol, triglycerides and high density lipoproteins.
\end{abstract}

Key Words: Running, Swimming, Biochemical Variables, Cholesterol, Triglycerides, High-density Lipoprotein

\section{INTRODUCTION}

Training means preparing for something: an event a season, an athletic competition, a nursing career, an operatic performance, or military combat. Much growth and change occur during training. It usually involves learning or polishing skills, exchanging attitudes and developing and strengthening organs and their functions. When we train, we have something in mind; a goal, a level of competence, a performance of some kind. An aspiration is established in our mind, which we systematically pursue. We get prepared to meet the increasing demands of some kind with respect to our current mental or physical resources. We seek, in some way, to change and better our present status, to improve on our previous level of performance.

The interval training in which bouts of hard running or work are separated by periods of light exercise with no pause for rest. Interval training involves intense exercise interspersed with intervals of relatively light exercise. To improve card io respiratory functioning, strenuous intervals should be allowed at near-maximum heart rate intensity. This form of training usually results in a greater buildup of lactate, accompanied by greater pain and discomfort. However, since the overload principle i s applied-that is, the length or intensity of intervals can be increased-great improvement in fitness can occur in a short period of time $[1-3]$.

At swim smooth we know the secret of freestyle breathing. The secret is good exhalation. Whenever our face is in the water, exhale constantly and smoothly. When we are swimming we should always be exhaling except when we turn our head to inhale. We can exhale through our mouth or through our nose or through both, it doesn't matter. But when our face is in the water we should be exhaling all the time in one constant stream of bubbles.

As lipids are insoluble, cholesterol cannot be carried in the blood in its original form. It has to be carried by protein 
molecules called lipoproteins, in which cholesterol is encompassed and carried to and away from the tissues. There are four types of lipoproteins; based on their density they are named High-Density Lipoprotein (HDL), Low-Density Lipoprotein (LDL), Very Low-Density Lipoprotein (VLDL) and Chylomicrons [2-7].

The American Heart Association, the British Heart Foundation and the World Health Organization were satisfied with the role of physical activity in prevention of coronary heart disease and listed physical inactivity as a risk factor for CHD along with other risk factors such as hypertension, smoking, diabetes, hypercholesterolemia etc., and recommended that in all CHD prevention programmes. Regular physical activity should be promoted alongside the blood pressure control and regulation to lower cholesterol.

\section{Methodology}

The purpose of the study was to find out the effect of interval running and swimming activities on selected biochemical variables. To achieve this purpose of the study, thirty male teachers aged between 35 and 40 years who knows swimming were contacted and randomly selected as subjects. They were divided into three equal groups, each group consisted of ten subjects in which Group I underwent running activity and group II underwent swimming activity three days per week for twelve weeks and group III acted as control, who did not participate in any training. The subjects were tested on selected criterion variables such as total cholesterol, triglycerides and high-density lipoprotein at prior to and immediately after the training period. The selected criterion variables such as total cholesterol, triglycerides and high-density lipoprotein were measured by Boehringer Mannheim kit method. The analysis of covariance (ANCOVA) was used to find out the significant difference if any, between the experimental groups on selected criterion variables separately. In all the cases, .05 level of confidence was fixed to test the significance, which was considered as an appropriate. Since three groups were involved in the present study, the Scheffé $S$ test was used as post-hoc test to find out which the paired mean was significantly differ.

Cooper test was administered for both interval running and swimming activity groups to find out their maximum performance. For the running group, the initial load was fixed individually in accordance with their maximum distance covere $\mathrm{d}$ in 12 minutes. For swimmers, the distance covered in 12 minutes was recorded and converted into swimming distance as recommended by Fox and Mathews. The training distance of swimming group was found to be one fourth of their running distance in 12 minutes. During the initial week, the warming up period and warming down period was fixed as nine and six minutes respectively for running activity and swimming activity groups and it has increased half a minute in each week from $t$ he second week to twelfth week for both the groups.

\section{Training Programme for Running Group}

Interval training programme is designed individually on the basis of the initial Cooper test performance (initial load fixed on $55 \%$ of individual initial performance). From the I week to the VI week running distance intensity increased from $55 \%$ to $80 \%$ each individual could complete their stipulated distance within 12 minutes with two repetitions with a rest of 8 minu tes between repetitions. After completion of the VI week the load intensity was constant up to $\mathrm{t}$ welfth week, but the over load principle adopted through decrease the rest period. For the VII and the VIII week rest period in between repetition was 7 minutes, for the IX and the X week the rest between repetitions was reduced to 6 minutes, and the XI and the XII week rest given was only in 5 minutes.

\section{Training programme for Swimming Group}

Interval training programme was constituted individually on the basis of their initial cooper test performance. Swimming distance was calculated by converting their running distance into swimming distance on the basis of Fox formula: $1 / 4$ of running distance is equal to swimming distance (i.e. if a person runs $200 \mathrm{mts}$ it treated on a par with the swimming distan ce of $50 \mathrm{mts}$.). Initial load fixed on the $55 \%$ of each individuals Cooper test performance for swimmers converted swimming distance. From I week to VI week swimming distance intensity was raised from $55 \%$ to $80 \%$. Each individual could complete the 
stipulated distance within 12 minutes with two repetitions with a rest period of 8 minutes between repetitions. After completing the VI week training, the load intensity was constant up to twelfth week (80\%). But the overload principle adopted through decrease the recovery period. For the VII and the VIII week recovery period in between repetition was 7 minutes, IX and X week recovery period in between repetition was 6.5 minutes and XI and XII recovery period in between repetition was 6 minutes.

Table - I

Analysis of Covariance and „, $F^{\prime \prime}$ ratio on Selected Biochemical Variables for Running Activity, Swimming Activity and Control Groups

\begin{tabular}{|c|c|c|c|c|c|}
\hline Variable Name & Group Name & $\begin{array}{c}\text { Running Activity } \\
\text { Group }\end{array}$ & $\begin{array}{c}\text { Swimming } \\
\text { Activity Group } \\
\end{array}$ & Control Group & 'F' Ratio \\
\hline \multirow{3}{*}{$\begin{array}{c}\text { Total Cholesterol } \\
\text { (mg/dl) }\end{array}$} & $\begin{array}{c}\text { Pre-test Mean } \pm \\
\text { S.D }\end{array}$ & $192.00 \pm 9.933$ & $195.30 \pm 11.538$ & $194.70 \pm 5.599$ & 0.352 \\
\hline & $\begin{array}{l}\text { Post-test Mean } \pm \\
\text { S.D. }\end{array}$ & $188.90 \pm 10.567$ & $192.70 \pm 11.681$ & $200.50 \pm 9.513$ & 3.099 \\
\hline & $\begin{array}{c}\text { Adj. Post-test } \\
\text { Mean }\end{array}$ & 190.981 & 191.347 & 199.772 & 13.263 \\
\hline \multirow{3}{*}{$\begin{array}{l}\text { Triglycerides } \\
\text { (mg/dl) }\end{array}$} & $\begin{array}{c}\text { Pre-test Mean } \pm \\
\text { S.D }\end{array}$ & $137.9 \pm 12.78$ & $141.9 \pm 12.05$ & $147.9 \pm 15.55$ & 1.381 \\
\hline & $\begin{array}{c}\text { Post-test Mean } \pm \\
\text { S.D. }\end{array}$ & $130.3 \pm 13.29$ & $134.8 \pm 14.67$ & $150.4 \pm 13.16$ & $5.907 *$ \\
\hline & $\begin{array}{c}\text { Adj. Post-test } \\
\text { Mean }\end{array}$ & 134.599 & 135.414 & 145.487 & $9.959 *$ \\
\hline \multirow{3}{*}{$\begin{array}{l}\text { High Density } \\
\text { Lipoproteins } \\
\text { (mg/dl) }\end{array}$} & $\begin{array}{c}\text { Pre-test Mean } \pm \\
\text { S.D }\end{array}$ & $45.20 \pm 3.084$ & $46.00 \pm 3.712$ & $43.70 \pm 2.312$ & 1.428 \\
\hline & $\begin{array}{l}\text { Post-test lMean } \pm \\
\text { S.D. }\end{array}$ & $49.90 \pm 3.143$ & $50.30 \pm 2.710$ & $42.90 \pm 2.283$ & $23.162 *$ \\
\hline & $\begin{array}{c}\text { Adj. Post-test } \\
\text { Mean }\end{array}$ & 49.710 & 49.458 & 43.932 & $82.298^{*}$ \\
\hline
\end{tabular}

* Significant at .05 level of confidence. (Table value required for significant at .05 level of confidence with df 2 and 27 and 2 and 26 are 3.35 and 3.37).

Table - II

Scheffẽ S Test for the Difference Between the Adjusted Post-Test Mean of Selected Criterion Variables

\begin{tabular}{|c|c|c|c|c|}
\hline \multicolumn{5}{|c|}{ Adjusted Post-test Mean on Total Cholesterol } \\
\hline $\begin{array}{c}\text { Running Activity } \\
\text { Group }\end{array}$ & $\begin{array}{c}\text { Swimming Activity } \\
\text { Group }\end{array}$ & Control group & Mean Difference & $\begin{array}{c}\text { Confidence } \\
\text { interval at } .05 \\
\text { level }\end{array}$ \\
\hline 190.981 & & 199.772 & $8.791 *$ & 5.0042 \\
\hline \multirow[t]{2}{*}{190.981} & 191.347 & & 0.366 & 5.0042 \\
\hline & 191.347 & 199.772 & $8.425^{*}$ & 5.0042 \\
\hline \multicolumn{5}{|c|}{ Adjusted Post-test Mean on Triglycerides } \\
\hline $\begin{array}{c}\text { Running Activity } \\
\text { Group }\end{array}$ & $\begin{array}{c}\text { Swimming Activity } \\
\text { Group }\end{array}$ & Control group & Mean Difference & $\begin{array}{c}\text { Confidence } \\
\text { interval at } .05 \\
\text { level }\end{array}$ \\
\hline
\end{tabular}




\begin{tabular}{|c|c|c|c|c|}
\hline 134.599 & & 145.487 & $10.888^{*}$ & 6.75867 \\
\hline \multirow[t]{2}{*}{134.599} & 135.414 & & 0.815 & 6.75867 \\
\hline & 135.414 & 145.487 & $10.073^{*}$ & 6.75867 \\
\hline \multicolumn{5}{|c|}{ Adjusted Post-test Mean on High Density Lipoproteins } \\
\hline $\begin{array}{c}\text { Running Activity } \\
\text { Group }\end{array}$ & $\begin{array}{c}\text { Swimming Activity } \\
\text { Group }\end{array}$ & Control group & Mean Difference & $\begin{array}{c}\text { Confidence } \\
\text { interval at } .05 \\
\text { level }\end{array}$ \\
\hline 49.710 & & 43.932 & $5.778^{*}$ & 1.26654 \\
\hline \multirow[t]{2}{*}{49.710} & 49.458 & & 0.252 & 1.26654 \\
\hline & 49.458 & 43.932 & $5.526^{*}$ & 1.26654 \\
\hline
\end{tabular}

* Significant at .05 level of confidence.

\section{Results:}

Table - I showed that there was a significant difference among running activity group, swimming activity group and control group on total cholesterol, triglycerides and high density lipoproteins.

Table - II shows that the Scheffẽ $S$ Test for the adjusted post-test mean difference on total cholesterol between running activity and control groups (8.791) and swimming activity and control groups (8.425), which were significant at .05 level of confidence. There was no significant difference between running activity group and swimming activity group (0.366) on total cholesterol after the training programme.

Table - II also shows that the Scheffẽ $S$ Test for the adjusted post-test mean difference on triglycerides between running activity and control groups (10.888) and swimming activity and control groups (10.073) were significant at .05 level of confidence. But there was no significant difference between running activity and swimming activity groups (0.815) on trilgycerdies after the training programme.

Table - II shows that the Scheffẽ $S$ Test for the difference between adjusted post-test means on high density lipoproteins between running activity and control groups (5.778) and swimming activity and control groups (5.526) were significant at .05 level of confidence. But there was no significant difference between running activity and swimming activity groups (0.252) on high density lipoproteins after the training programme.

\section{Conclusions:}

Based on the results of the study, the following conclusion were drawn:

1. Participation in physical training resulted in a significant decrease in total cholesterol and triglycerides and a rise in high-density lipoprotein level on experimental groups when compared with control group. 
2. There was no significant difference between running activity group and swimming groups on selected criterion variables.

\section{Reference:}

[1]. Rajeev Gupta, H. Prakash, V.P. Gupta, K.D. Gupta, Prevalence and determinants of coronary heart disease in a rural population of India, Journal of Clinical Epidemiology, 50 (1997) 203-209..

[2]. Greenberg Jerrold S. and David Pargman, Physical Fitness: A Wellness Approach, (Englewood Cliffs: Prentice Hall Inc., 1989), p.43.

[3]. E.A. Enas, and A. Senthilkumar, Conquering the Epidemic of Coronary Artery Disease Among Indians: Crucial Role of Cardiology, Cardiology Today, 5 (2001) 282-294.

[4]. Otto Appenzeller, Sports Medicine and Fitness, ( $3^{\text {rd }}$ ed), (Baltimore: Urban and Schawerzenegger, 1988), p. 222.

[5]. Thomas M. Scotti and Donald B. Hackel, Incidence of CHD in U.S.A, Anderson Pathology, John M. Kissane, ed., (St. Louis: The C.V. Mosby Company, 1985), p. 578.

[6]. David H. Clarke, Exercise Physiology, (Englewood Cliffs, New Jersey: Prentice Hall Inc., 1975), p. 249.

[7].Edward L. Fox and Donald K. Mathews, The Physiological Basis of Physical Education and Athletics, (Philadelphia: Saunders College Publishing, 1981), p. 278. 